\title{
RECEIVED
}

\section{FEB 121997}

OSTI

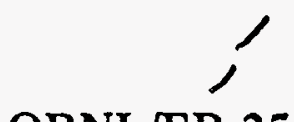

ORNL/ER-254
ENVIRONMENTAL RESTORATION PROGRAM

\section{Project Management Plan for the Gunite and Associated Tanks Treatability Studies Project at Oak Ridge National Laboratory, Oak Ridge, Tennessee}

MANAGED BY

MARTIN MARIETTA ENERGY SYSTEMS, INC.

FOR THE UNITED STATES

DEPARTMENT OF ENERGY

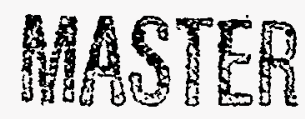

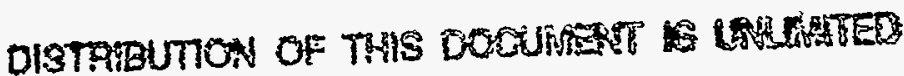

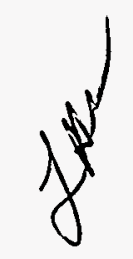

ENERGYSYSTEMS 
Jacobs Engineering Group Inc.

and Gilbert/Commonwealth, Inc.

contributed to the preparation of this document and should not be considered an eligible contractor for its review.

This report has been reproduced directly from the best available copy.

Avallable to DOE and DOE contractors from the Office of Scientific and Technical Information, P.O. Box 62, Oak Ridge, TN 37831; prices available from 615-576-8401.

Available to the public from the National Technical Information Service, U.S. Department of Commerce, 5285 Port Royal Rd., Springfield, VA 22161. 
DISCLAIMER

This report was prepared as an account of work sponsored by an agency of the United States Government. Neither the United States Government nor any agency thereof, nor any of their employees, makes any warranty, express or implied, or assumes any legal liability or responsibility for the accuracy, completeness, or usefulness of any information, apparatus, product, or process disclosed, or represents that its use would not infringe privately owned rights. Reference berein to any specific commercial product, process, or service by trade name, trademark, manufacturer, or otherwise does not necessarily constitute or imply its endorsement, recommendation, or favoring by the United States Government or any agency thereof. The views and opinions of authors expressed herein do not necessarily state or reflect those of the United States Government or any agency thereof. 


\section{DISCLAIMER}

Portions of this document may be illegible electronic image products. Images are produced from the best available original document. 
ORNL/ER-254

Energy Systems Environmental Restoration Program

Project Management Plan

for the Gunite and Associated Tanks

Treatability Studies Project

at Oak Ridge National Laboratory,

Oak Ridge, Tennessee

Date Issued-December 1995

Prepared by

Lockheed Martin Energy Systems, Inc.

and

Jacobs Engineering Group Inc.

125 Broadway Avenue

Oak Ridge, Tennessee 37830

under contract DE-AC05-93OR22028

Prepared for the

U.S. Department of Energy

Office of Environmental Management

under budget and reporting code EW 20

Environmental Management Activities at OAK RIDGE NATIONAL LABORATORY

Oak Ridge, Tennessee 37831-6285

managed by

LOCKHEED MARTIN ENERGY SYSTEMS, INC.

for the

U.S. DEPARTMENT OF ENERGY

under contract DE-AC05-84OR21400 
Project Management Plan for the Gunite and Associated Tanks Treatability Studies Project at Oak Ridge National Laboratory,

Oak Ridge, Tennessee

ORNL/ER-254

APPROVALS

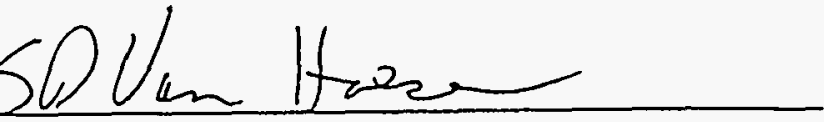

S. D. Van Hoesen

Lockhced Martin Energy Systems, Inc.

Oak Ridge National Laboratory

GAAT Treatability Studies Project Manager

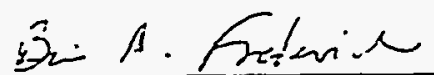

B. Frederick

Jacobs Engineering

GAAT Treatability Studies Deputy Project Manager

Quen W. Yyale

O. W. Hale

Lockheed Martin Energy Systems, Inc.

Oak Ridge National Laboratory

GAAT Treatability Studies Engineering Manager

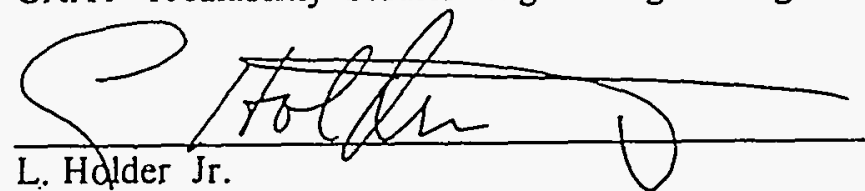

Lockhoed Martin Energy Systems, Inc.

Oak Ridge National Laboratory

GAAT Treatability Studies Facility Manager

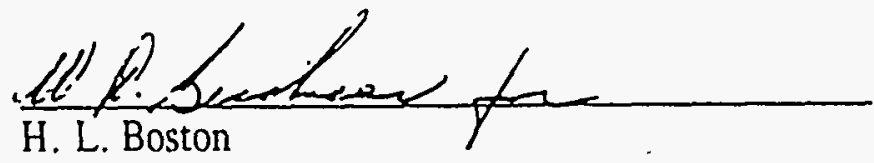

Lockheed Martin Energy Systems, Inc.

Oak Ridge National Laboratory

Environmental Resto aton Program Manager

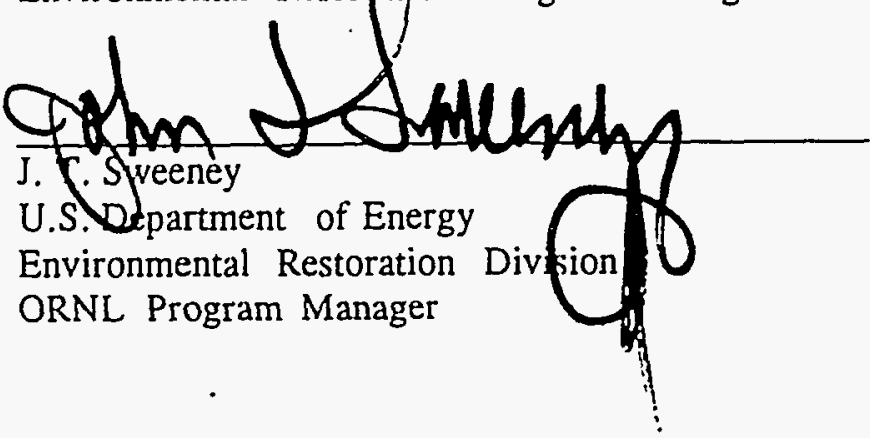

Date: $1 / 4 / 95$

Date: $: 19 / 95$
Date: $12 / 16 / 94$

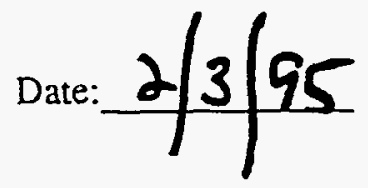




\section{PREFACE}

This Project Management Plan for the Gunite and Associated Tanks Treatability Study at Oak Ridge National Laboratory (ORNL/ER-254) establishes how the project conducts operations. The project itself is conducted in accordance with the Treatability Study Work Plan (DOE/OR/021300\&D2), which is a Federal Facility Agreement Milestone. The purpose of this project is a Comprehensive Environmental Response, Compensation, and Liability Act (CERCLA) required waste characterization and remediation study to be conducted at Oak Ridge National Laboratory from FY 1994 to FY 1997. This work is being performed under Work Breakdown Structure 6.1.01.41.12.04 (Activity Data Sheet 3301 "ORNL WAG 1 Treatability Studies for Gunite and Associated Tanks Operable Unit"). 



\section{CONTENTS}

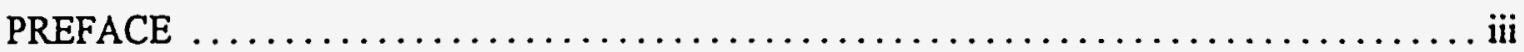

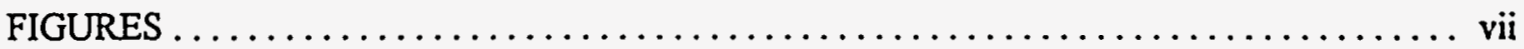

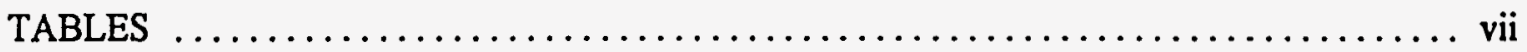

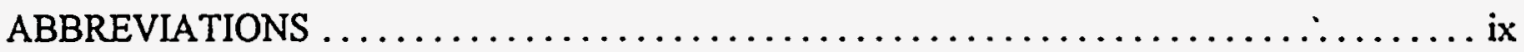

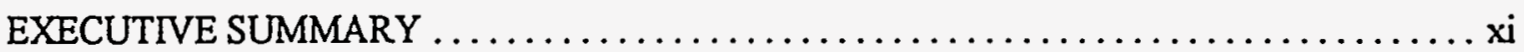

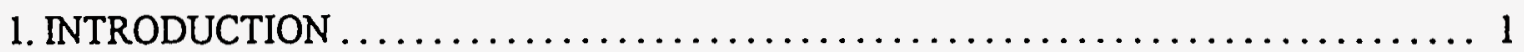

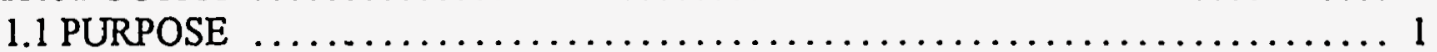

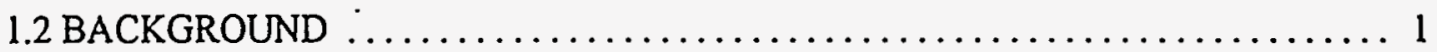

1.3 THE CERCLA TREATABILITY STUDY PROCESS $\ldots \ldots \ldots \ldots \ldots \ldots \ldots \ldots 6$

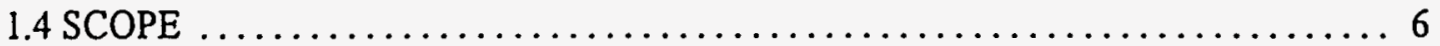

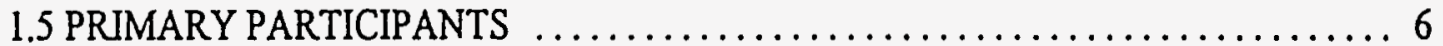

2. PERFORMANCE CRITERIA AND WORK PLANS $\ldots \ldots \ldots \ldots \ldots \ldots \ldots \ldots \ldots \ldots$

2.1 PERFORMANCE CRITERIA $\ldots \ldots \ldots \ldots \ldots \ldots \ldots \ldots \ldots \ldots \ldots \ldots \ldots \ldots \ldots$

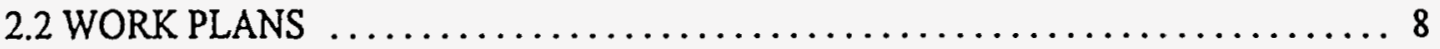

2.2.1 Project Management .......................... 8

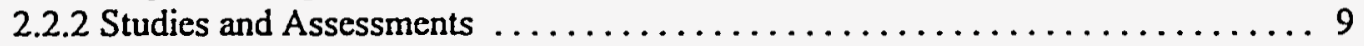

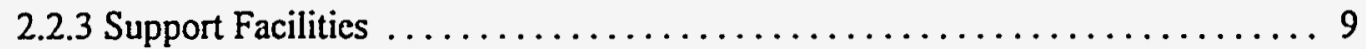

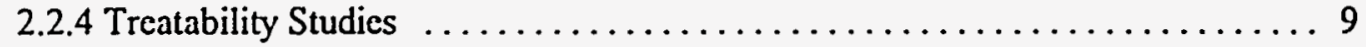

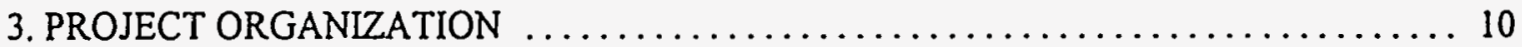

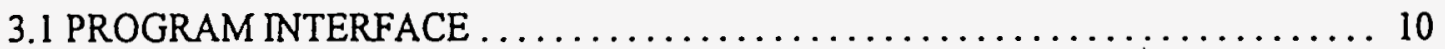

3.2 DETAILS OF PROJECT ORGANIZATION $\ldots \ldots \ldots \ldots \ldots \ldots \ldots \ldots \ldots \ldots \ldots$

4. SUMMARY LEVEL WORK BREAKDOWN STRUCTURE $\ldots \ldots \ldots \ldots \ldots \ldots \ldots \ldots$

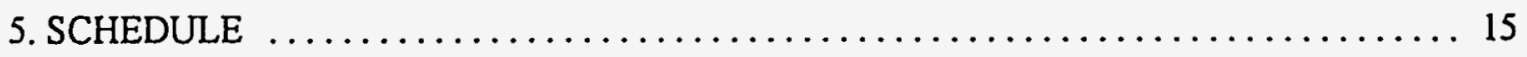

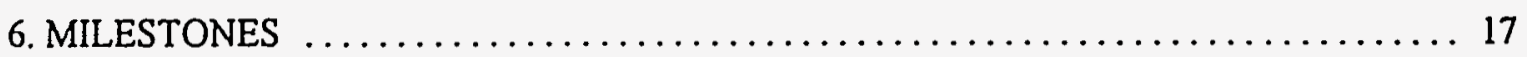

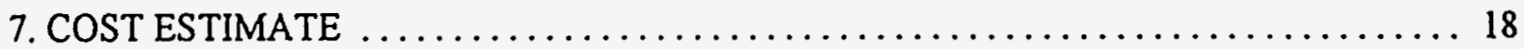

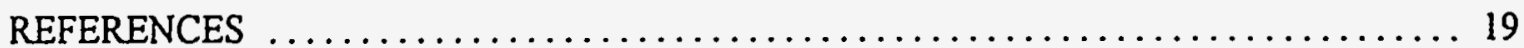




\section{.}




\section{FIGURES}

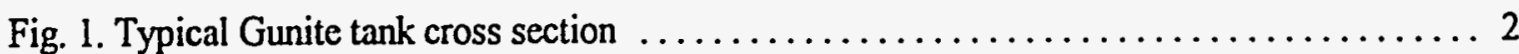

Fig. 2. Location of inactive waste storage tanks at the ORNL main plant site $\ldots \ldots \ldots \ldots \ldots \ldots 3$

Fig. 3. Cross section of Gunite tank during operations in $1984 \ldots \ldots \ldots \ldots \ldots \ldots \ldots \ldots$.

Fig. 4. ORNL ER Program organization chart $\ldots \ldots \ldots \ldots \ldots \ldots \ldots \ldots \ldots \ldots \ldots \ldots \ldots \ldots \ldots \ldots$

Fig. 5. GAAT Treatability Studies Project organization chart $\ldots \ldots \ldots \ldots \ldots \ldots \ldots \ldots \ldots, 12$

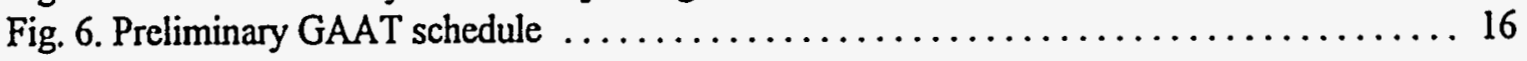

\section{TABLES}

Tablc 1. Gunite and associated tanks RI/FS remediation alternatives $\ldots \ldots \ldots \ldots \ldots \ldots \ldots$ 


\section{ABBREVIATIONS}

CERCLA Comprehensive Environmental Response, Compensation, and Liability Act of 1980

CET

DOE

Center for Environmental Technology

Energy Systems

EPA

ER

FFA

GAAT

JEG

ORNL

ORR

OTD

RU/FS

TDEC

WAG

U.S. Department of Energy

Lockheed Martin Energy Systems, Inc.

Environmental Protection Agency-Region IV

Environmental Restoration

Federal Facility Agreement

Gunite and Associated Tanks

Jacobs Engineering Group Inc.

Oak Ridge National Laboratory

Oak Ridge Reservation

Office of Technology Development

Remedial Investigation/Feasibility Study

Tennessee Department of Environment and Conservation

Waste Area Grouping 


\section{EXECUTIVE SUMMARY}

This project management plan describes the scope and objectives for the Gunite and Associated Tanks (GAAT) Treatability Studies Project of the Oak Ridge National Laboratory (ORNL) Environmental Restoration (ER) Program. This plan will serve as the project-specific management plan as called for in ORNL ER Program Management Plan ORNL/ER-167 (Energy Systems 1994).

This document is intended to explain how the GAAT Treatability Studies Project does business. The management structure of the project is described in detail in this plan. The various personnel matrixed to the project for the completion of specific assignments are identified. This plan also identifies the interactions between the GAAT Treatability Studies Project and ER Program personnel.

Separate sections of the report describe performance criteria and work plans, project organization, project summary work breakdown structure, schedule, milestones, and summary cost estimate. 



\section{INTRODUCTION}

\subsection{PURPOSE}

This plan for the Gunite and Associated Tanks (GAAT) Treatability Studies Project satisfies the requirements of the program management plan for the Oak Ridge National Laboratory (ORNL) Environmental.Restoration (ER) Program as established in the Program Management Plan for the Martin Marietta Energy Systems, Inc., Oak Ridge National Laboratory Site Environmental Restoration Program. ORNL/ER-167 (Energy Systems 1994).This plan is a subtier of several other ER documents designed to satisfy the U.S. Department of Energy (DOE) Order 4700.1 requirement for major systems acquisitions.

This project management plan identifies the major activities of the GAAT Treatability Studies Project; establishes performance criteria; discusses the roles and responsibilities of the organizations that will perform the work; and summarizes the work breakdown structure, schedule, milestones, and cost estimate for the project.

\subsection{BACKGROUND}

In 1943, the Clinton Laboratories were built in Oak Ridge, Tennessee, to serve as a pilot facility for production operations at Hanford, Washington. The work included construction of six large underground concrete (Gunite) tanks (designated W-5 through W-10) for storage of wastes that might be generated at the Laboratories. Construction was started in April 1943, and the tanks were in operational use in November 1943. These tanks have an inside diameter of $50 \mathrm{ft}$, a sidewall height of $12 \mathrm{f}$, and a capacity of $643,000 \mathrm{~L}(170,000 \mathrm{gal})$. A schematic illustration of the tanks is provided in Fig. 1. Six smaller Gunite tanks and four stainless stecl tanks constitute the rest of the GAAT. The name of the Clinton Laboratories was changed to the Oak Ridge National Laboratory (ORNL), and the waste storage tanks became an integral part of the ORNL waste system. The initial six tanks became part of what is historically called the South Tank Farm, and the four steel tanks and four of the smaller Gunite tanks became part of what has been historically called the North Tank Farm. The remaining two smaller Gunite tanks (W-11 and TH-4) are located a short distance from the South Tank Farm. A site overview showing the tank locations is provided in Fig. 2.

The radioactive, hazardous, and other chemical wastes handled by these tanks have been routinely treated with caustic to a $\mathrm{pH}$ of 10 or greater; substances that are insoluble in high $\mathrm{pH}$ solutions precipitated and settled in the waste storage tanks. In 1980, when the ORNL waste system was revised and these tanks were taken out of service, about 1.5 million liters $(400,000$ gal) of sludge containing between 0.5 and 1 million curies had accumulated in the tanks. Subsequent characterization of the tanks indicated transuranic and Resource Conservation and Recovery Act materials were also present in the tanks.

A program to empty the original six tanks and dispose of the accumulated sludge began in 1977 . Process development, system design, and facility construction were completed by Junc 1982. In approximately 18 months of operation, sludge in five of the six 170,000-gal tanks was removed by sluicing (see Fig. 3 for the sluicing system layout). Through the use of this technique, the sludge was resuspended in a water $-2.5 \%$ bentonite mixture. Bentonite was used to suspend the sludge and 


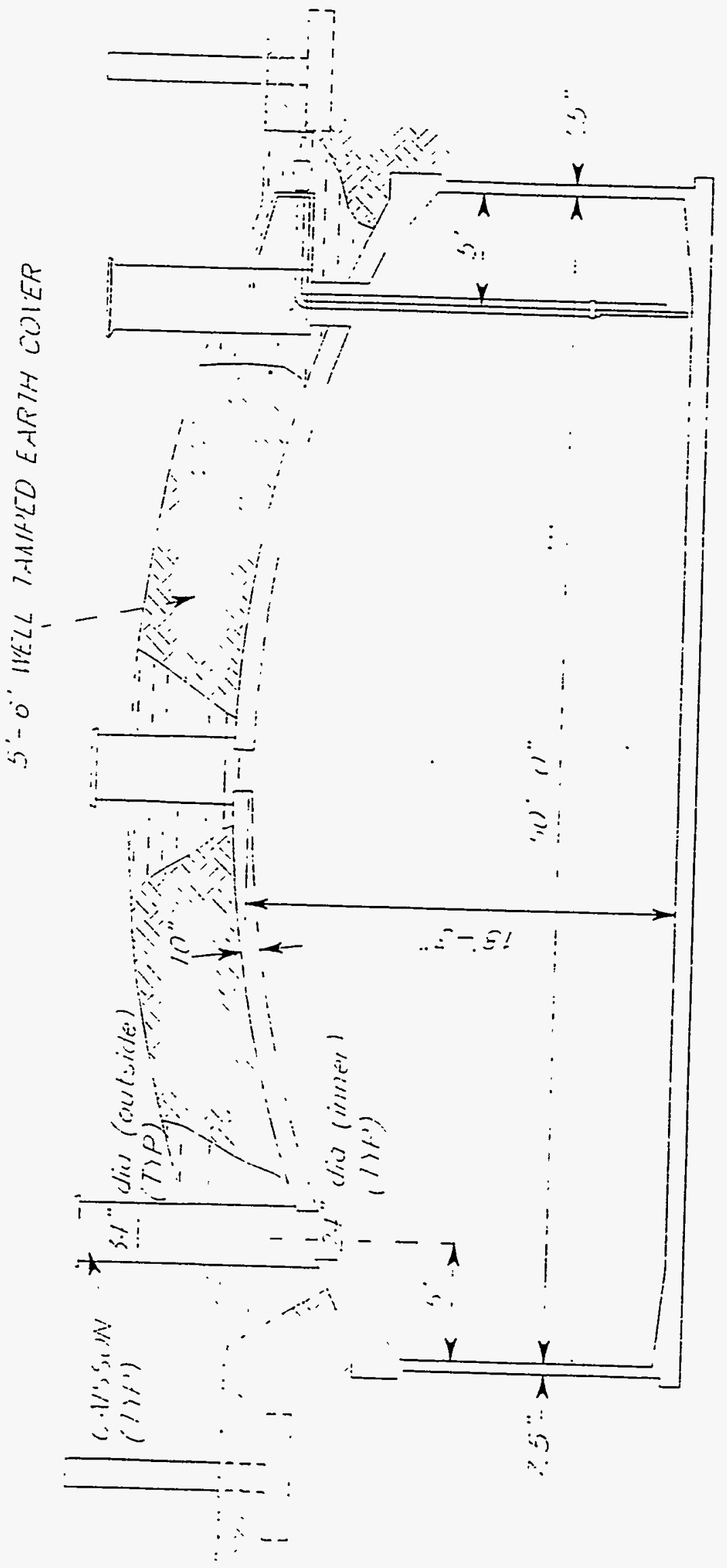

 
彭言高咅旁

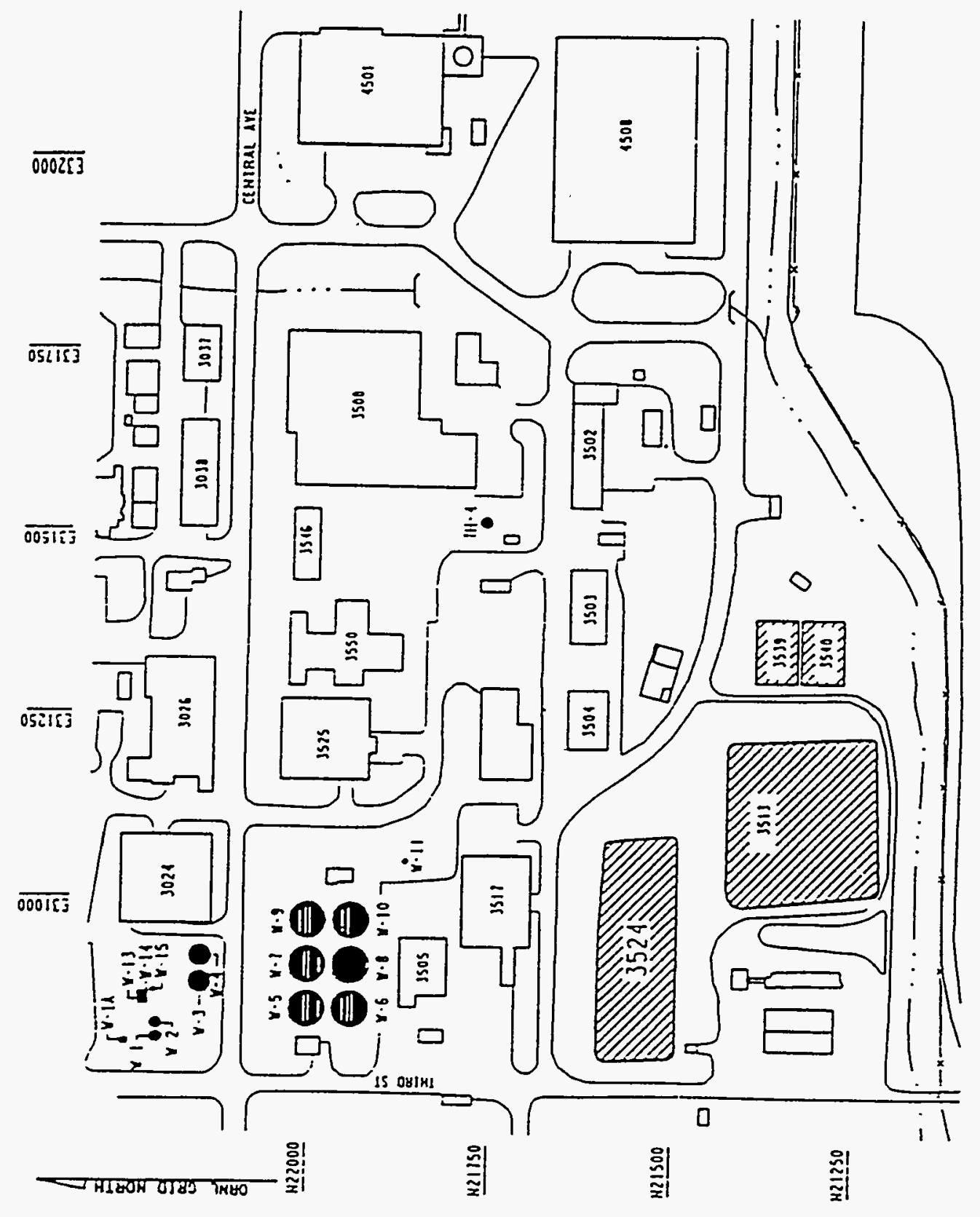

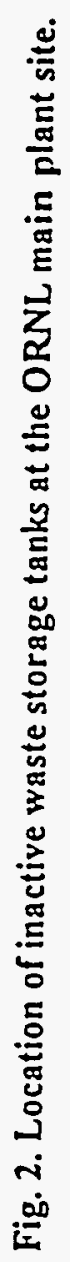




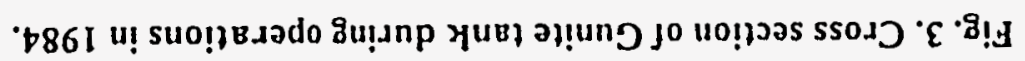

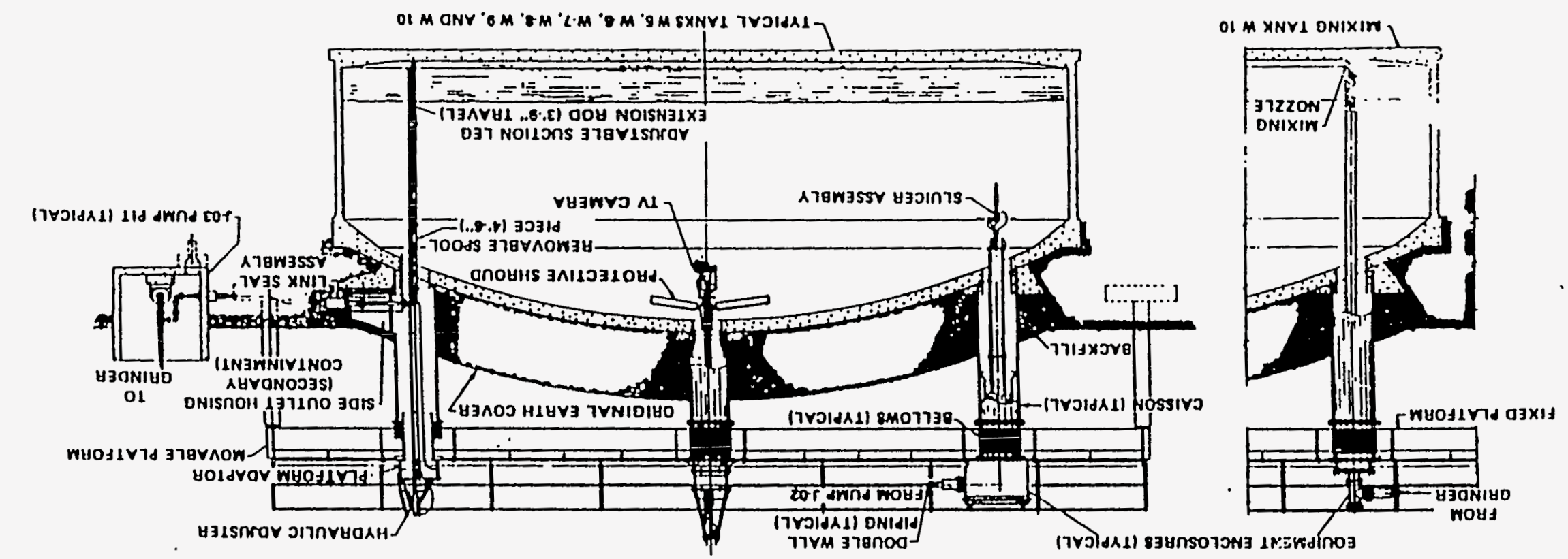

5090128 2MO - INบO 
extend the time before the sludge settled. Approximately $90 \%$ of the sludge was resuspended, pumped to the Melton Valley storage tanks, then transferred to the hydrofracture site for temporary storage, and subsequently, permanent disposal. Following this operation, the amount of sludge remaining in these tanks was estimated at about $216,000 \mathrm{~L}$ ( $57,000 \mathrm{gal})$, approximately $80 \%$ of which resides in tanks W- 6 and $\mathrm{W}-10$.

In 1989, the Oak Ridge Reservation (ORR) was placed on the National Priorities List and the Comprehensive Environmental Response, Compensation, and Liability Act of 1980 (CERCLA) remediation process was initiated. The tanks described previously were combined into the GAAT operable unit located within Waste Area Grouping (WAG) 1. In January 1992, the Federal Facility Agreement (FFA) was adopted by DOE, Environmental Protection Agency-Region IV (EPA), and Tennessee Department of Environment and Conservation (TDEC). Under the FFA, the Remedial Investigation/Feasibility Study (RI/FS) for the GAAT was to be issued to EPA and TDEC for comment by May 2, 1994. The RJ/FS-prepared by DOE, Lockheed Martin Energy Systems, Inc. (Energy Systems), Bechtel National, Inc., CDM Federal Programs, Radian, and Jacobs Engineering Group Inc. (JEG) - contained information on the nature and extent of contamination in tanks and surrounding -media, and evaluated seven remediation alternatives (Table 1 ) which reflected a range of removal, treatment, and disposal options, including "no action."

Table 1. Gunite and associated tanks RUFS remediation alternatives

\begin{tabular}{|c|l||}
\hline Alternative & \multicolumn{1}{c|}{ Descriptions } \\
\hline 1 & No action, institutional controls only \\
\hline 2 & Tank stabilization, no sludge treatment \\
\hline 3 & In situ sludge fixation in each tank \\
\hline 4 & Remove sludge, in situ fixation/consolidation \\
\hline 5 & Remove sludge, treatment/storage at ORR \\
\hline 6 & $\begin{array}{l}\text { Remove sludge, treatment/disposal via DOE } \\
\text { transuranic waste program }\end{array}$ \\
\hline 7 & $\begin{array}{l}\text { Remove sludge, tanks, soils for treatment and } \\
\text { storage/disposal at ORR }\end{array}$ \\
\hline
\end{tabular}

During reviews of the RI/FS, DOE, Energy Systems, and JEG determined that significant technical and cost uncertainties existed that needed to be resolved in order to provide the basis for the decisions to be made in the Record of Decision. After discussion with EPA and TDEC, it was agreed that a series of treatability studies would be performed to reduce these uncertainties. The treatability studies are to be completed to support issue of the draft Feasibility Study by March 30, 1999, to be followed by the Proposed Plan and Record of Decision. 
The Remedial Investigation/Baseline Risk Assessment (DOE/OR/02-1275-R1) was submitted to DOE in May 1994.

A legally enforceable FFA milestone has been established which requires that detailed Treatability Study Plans, as called for in CERCLA, be prepared and submitted to the regulatory agencies by September 30, 1994. Based on the investigations conducted as part of the RI/FS, it is anticipated that treatability studies will be conducted in the areas of waste and residual characterization, unconfined and confined sluicing, deployment systems (remotely operated vehicle and arm), treatment systems, stabilization, and sludge transfer.

\subsection{THE CERCLA TREATABILITY STUDY PROCESS}

The GAAT Treatability Studies Project will be conducted in accordance with the guidance provided in Guide for Conducting Treatability Studies Under CERCLA, (EPA/540/2-89/058). As discussed in this document, the CERCLA process provides encouragement to conduct treatability studies to provide site-specific data necessary to aid in the selection and implementation of a remedy. The guide describes a three-tiered approach for conducting treatability studies, consisting of (1) laboratory screening, (2) bench-scale testing, and (3) pilot-scale testing. Depending on the information gathered during site characterization and technology screening and the data gaps that exist, treatability studies may begin with any tier and may skip tiers that are not needed. The guide also presents a stepwise approach or protocol for conducting treatability studies for determination of the effectiveness of a technology (or combination of technologies) in remediating a CERCLA site.

The results of the treatability studies to be conducted in this project are intended to be used to support preparation of the Feasibility Study for the remediation of the GAAT. It is intended that this Feasibility Study will support the preparation of a Proposed Plan and a Record of Decision for the GAAT remediation.

\subsection{SCOPE}

This project management plan identifies all activities necessary to implement the GAAT Treatability Studies Project. These activities include establishing data quality objectives; issuing the work assignments; preparing the work plans; preparing the sampling and analysis plans; preparing required project plans (e.g., health, safety, and waste management plans); preparing design and procurement packages; complying with regulatory requirements; executing the treatability studics; analyzing and interpreting the data; reporting the results; and conducting community relations activities. The methods of accomplishment will be determined during the Phase II, following final selection of subcontractors to support this project. This plan will be revised or appended at that time to include the methods of accomplishment.

\subsection{PRIMARY PARTICIPANTS}

The GAAT Treatability Studies Project will be a joint venture conducted primarily by Encrgy Systems in its role as the Integrating Contractor and facility manager, and by JEG in its rolc as Technical Support Contractor. These organizations and their subcontractors will perform the planning, enginecring, and procurement activities required for the treatability studies. Since the treatability studies are research 
and development activities and require close coordination with ongoing ORNL operations (e.g., waste management and security) and facility management activities, Energy Systems forces and/or service subcontractors will perform operations activities required to conduct the treatability activities. Any activities determined to be "construction" (e.g., new facility construction) will be performed by MKFerguson Company of Oak Ridge in its role as the Construction Manager. 


\section{PERFORMANCE CRITERIA AND WORK PLANS}

\subsection{PERFORMANCE CRITERIA}

The following performance criteria will be met during the conduct of the GAAT Treatability Studies Project:

- The health and safety of workers involved in the treatability studies will be maintained as the top priority in planning and conducting actions.

- All activities will be conducted in full conformance with all applicable laws and regulations.

- A graded approach will be utilized in application of DOE Orders and guidance, and in application of Energy Systems procedures and guidance consistent with ensuring that personnel, the environment, and facilities are protected and government funds are efficiently utilized.

- The project will be conducted in accordance with the Life Cycle Baseline Summary for the Environmental Restoration Program for WAG 1.

- Treatability studies will be conducted in conformance with the Federal Facility Act (FFA) and the guidance provided in EPA/540/2-89/058.

- Activities will be coordinated and integrated with ORNL site, Waste Management Operations, and ORNL Decontamination and Decommissioning Program activities.

- Activities will be conducted to maximize utilization of technologies being developed by the Office of Technology Development (OTD), and the experience and information gained during the project will be transferred back to OTD.

- The project will be conducted to provide the information necded to support issuc of the draft Feasibility Study by March 30, 1999.

\subsection{WORK PLANS}

The gencral work plan for the project described in the following sections reflects the project summary work breakdown structure contained in Sect. 4. Each of the work activitics is described in the following sections.

\subsubsection{Project Management}

These activities include project management, project tracking and reporting, facility management, community relations, waste management interface, health and safety support, quality assurancc support, training coordination, and compliance support. The following project-level documents are planned to be prepared as part of this effort: project management plan, quality assurance project plan, training needs assessment, fiscal year work plans, baseline document, baseline change proposals, monthly status reports, and project tracking system inputs. Although attempts will be made to avoid duplication and 
utilize higher level documents wherever possible, it is expected that the following subproject-level documents will be required for each individual project work activity: work plan and procedures, safety review, waste management plan, health and safety hazard addendum, and best management practices plan.

\subsubsection{Studies and Assessments}

These activities include cost and scheduling support, information management support, and the conduct of a number of studies and assessments required to support project planning and implementation. Reports currently expected to be prepared include treatability study plan(s), risk model, as-built drawings, information management plan, tank enclosures study, tank structural evaluation and model, safety analysis report, technology review, tank characterization summary, sludge solubility study, categorical exclusion, and existing piping condition review. It is expected that additional documents will need to be prepared as project planning and implementation proceeds.

In addition, this activity is aimed at providing sampling and analytical support required to characterize the sludges, liquids, residues, and tank shell materials. It is expected that sampling and analytical activities will be conducted throughout the life of the project to support planning efforts and to provide information to determine the effectiveness of technologies utilized in the treatability studies. Some of the analytical data will be shared with the National Transuranic Program Office in support of waste characterization for the Waste Isolation Pilot Project. Initial efforts will focus on (1) establishing a task release with Bechtel National, Inc., to perform manual sampling; (2) developing plans with Energy Systems Analytical Chemistry Division to perform analysis; and (3) coordinating the sampling and characterization activities. Existing documents and procedures will be used to the maximum extent possible, although a sampling plan and updates to some existing documents are expected to be required. In addition, new equipment will neod to be procured to obtain core samples from the tank walls and floor and to map the location of sludges in the tanks.

\subsubsection{Support Facilities}

This activity is directed at performing the facility modifications and new construction needed to support conduct of the treatability studies. Utility extensions and upgrades, support platform modifications, staging areas and support trailers, piping, instrumentation, cold test facilities, etc., will be required. These requirements will be identified in functional requirements documents, which will be prepared as required.

\subsubsection{Treatability Studies}

This activity is directed at the performance of the treatability studies, and will be supported by conducting planning, procurement, and operations activities. It is anticipated that treatability studies will be conducted in the areas of waste and residual characterization, unconfined and confined sluicing, deployment systems (remotely operated vehicle and arm), treatment systems, tank stabilization, and sludge transfer. The need for the treatability studies will be determined through the CERCLA process referenced previously, and the individual treatability study plans will be developed as discussed in Sect. 2.2.2. Equipment, subcontractors, and facility support required to conduct the treatability studies will be provided through this activity. 


\section{PROJECT ORGANIZATION}

\subsection{PROGRAM INTERFACE}

Because of its importance and visibility, the GAAT Treatability Studies Project will report directly to the ORNL ER Remediation Manager as indicated in Fig. 4. Since GAAT is part of WAG 1, the GAAT Treatability Studies Project Manager will be responsible for coordinating and integrating activities with the WAG I Project Manager. All financial, schedule, and other related documents will be consistent with and incorporable into the WAG 1 level as required. The Project Manager will be responsible for project-level approval of all project activities including financial documents, reports, etc. Program-level approvals will be provided by the Remediation Manager, Deputy Program Manager, and/or Program Manager as appropriate.

\subsection{DETAILS OF PROJECT ORGANIZATION}

The organization of the project is shown in Fig. 5. The project participants and responsibilities are as outlined in the ORNL ER Program Management Plan (ORNL/ER-167) with the following exceptions.

The GAAT Treatability Studies Project Manager position has been established and will report to the Remediation Manager. The Project Manager will perform the same roles and responsibilities for the project as those of a WAG Project Manager, as defined in Sect. 4.2 of the ORNL ER Program Management Plan. The Project Manager will be responsible for integrating and coordinating the GAAT treatability studies activities with the WAG 1 Project Manager. For financial and schedule reporting activities, the GAAT Treatability Studies Project will continue be an operable unit that "rolls up" to WAG 1 .

To ensure close cooperation and integration and to further support the teaming arrangement between Energy Systems and JEG, a Deputy Project Manager position, to be filled by a JEG team member, has been established. The Deputy Project Manager will perform the functions of the Technical Support Contract Manager as described in Sect. 4.4 of the ORNL ER Program management plan and will assist and represent the Project Manager as needed. The Deputy Project Manager will be responsible for managing the activities of the Data Project Manager, Project Risk Assessment Coordinator, Project Estimator, and Project Scheduler. The Deputy Project Manager will also be responsible for project documentation preparation.

To maximize technology transfer between the GAAT Treatability Studies Project and other programs supporting technology development such as OTD and the Center for Environmental Technology (CET), Technology Development Coordinator positions have been established. The Technology Development Coordinators will provide coordination of project activities with OTD organizations supporting the GAAT treatability studies, including the Underground Storage Tank Integrated Demonstration Program; the Robotics Technology Development Program; the Characterization, Monitoring, and Sensor Technology Program; the Decontamination and Decommissioning Integrated Demonstration Program; and the Morgantown Energy Technology Center. In addition, the Technology Development Coordinators will coordinate project activities with CET. 


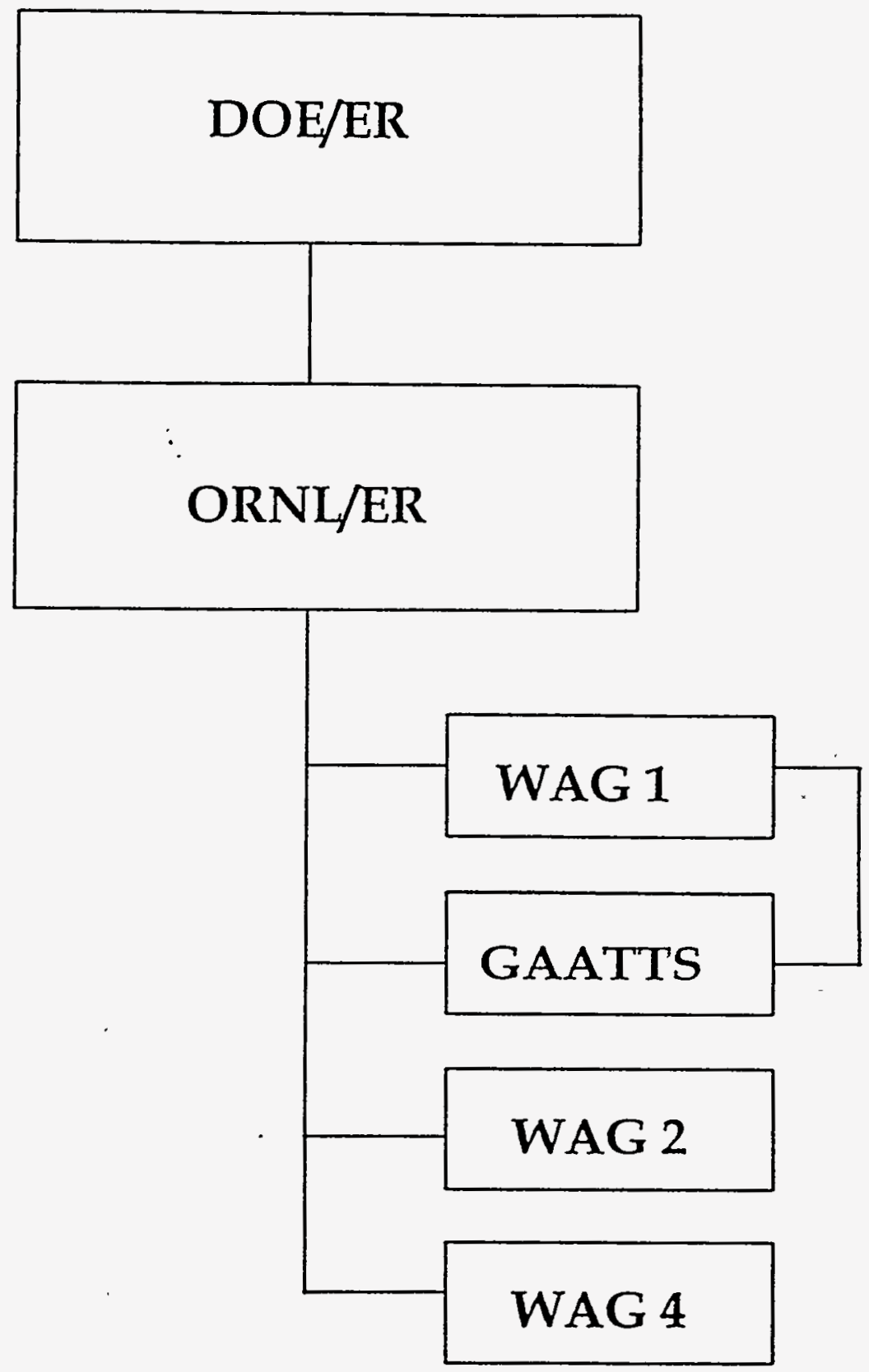

Fig. 4. ORNL ER Program organization chart. 


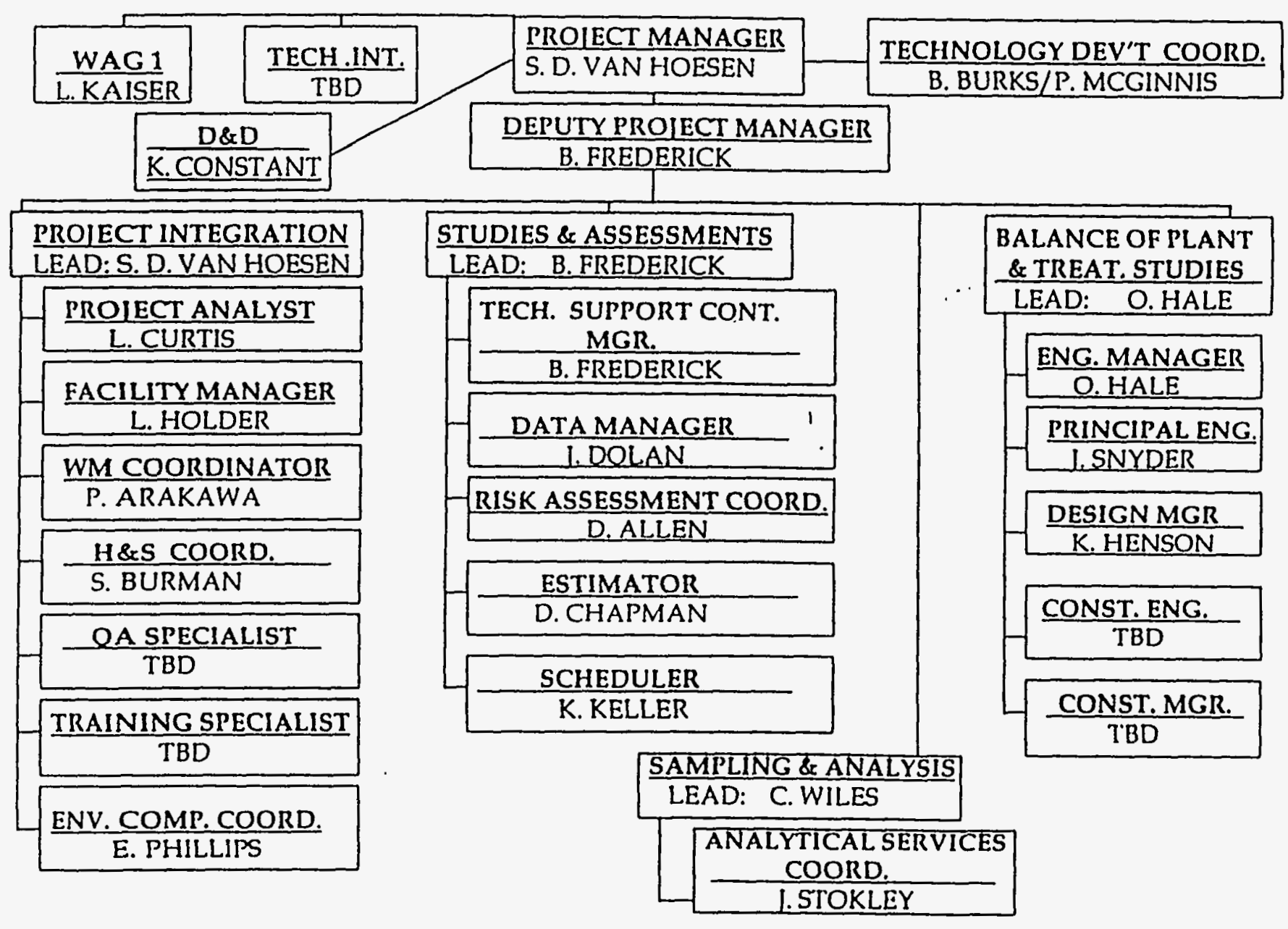

Fig. 5. GAAT Treatability Studies Project organization chart. 


\section{SUMMARY LEVEL WORK BREAKDOWN STRUCTURE}

The summary level work breakdown structure for the GAAT Treatability Studies Project is given here.

6.1.01.41.03.12 GAAT Treatability Studies

.12 .01 Treatability Studies Project Management

Project Manager

Project Analyst

Support (G/C)

Facility Manager

Public Involvement

Waste Management Coordination

Health and Safety

Environmental Compliance

Technology Development Coordination

Quality Assurance

Deputy Project Manager

$.12 \quad .02$

Studies and Assessments

Treatability Plans and Reports

Risk Modeling

As-configured Drawings

Information Management

Schedules

Cost Estimate

Enclosure Study

Structural Evaluation

Safety Review

Technology Review

Sampling Plan

Field Sampling and Analysis

Solubility Study

NEPA Support

Piping Integrity Study

Logistics Study

.16

.17

.12 .03

VE Study

.01

.02

Support Facilitics

Planning/Reporting

Engineering

Procurement/Construction

$.12 .04 \quad$ Treatability Studies

.01

Planning
Planning
Engineering
Procurement/Construction
Operations


Unconfined Sluicing

.01 Planning

.02 Engineering

Procurement/Construction Operations

End Effectors

.01 Planning

.02 Engineering

Procurement/Construction Operations

MLDUA Systems Deployment Planning Engineering Procurement/Construction Operations

Vehicle Systems Deployment

.01 Planning

.02 Engineering

.01 Planning

.02 Engineering Operations

Stabilization.

.01 Planning

$$
\text { Procurcment/Construction }
$$
Operations

Final Reports

.01 Planning

Procurement/Construction

.04 Operations

.09

Sludge Transfer

.01 Treatability Studies

.10

.02 Technology Demonstrations

Debris Removal

.01 Planning Engineering Procurement/Construction Operations Melton Valley Storage Tanks .01 Planning .02 Enginecring Procurement/Construction

$.04 \quad$ Operations 


\section{SCHEDULE}

Figure 6 is the summary project schedule for the GAAT Treatability Study and the GAAT CERCLA activities. This schedule provides information concerning the dates for completion of the phases for the GAAT Treatability Study for FY 1994 to FY 1997. In addition, the schedule also provides the information as to the completion of the CERCLA required activities for FY 1998 to FY 2000. 

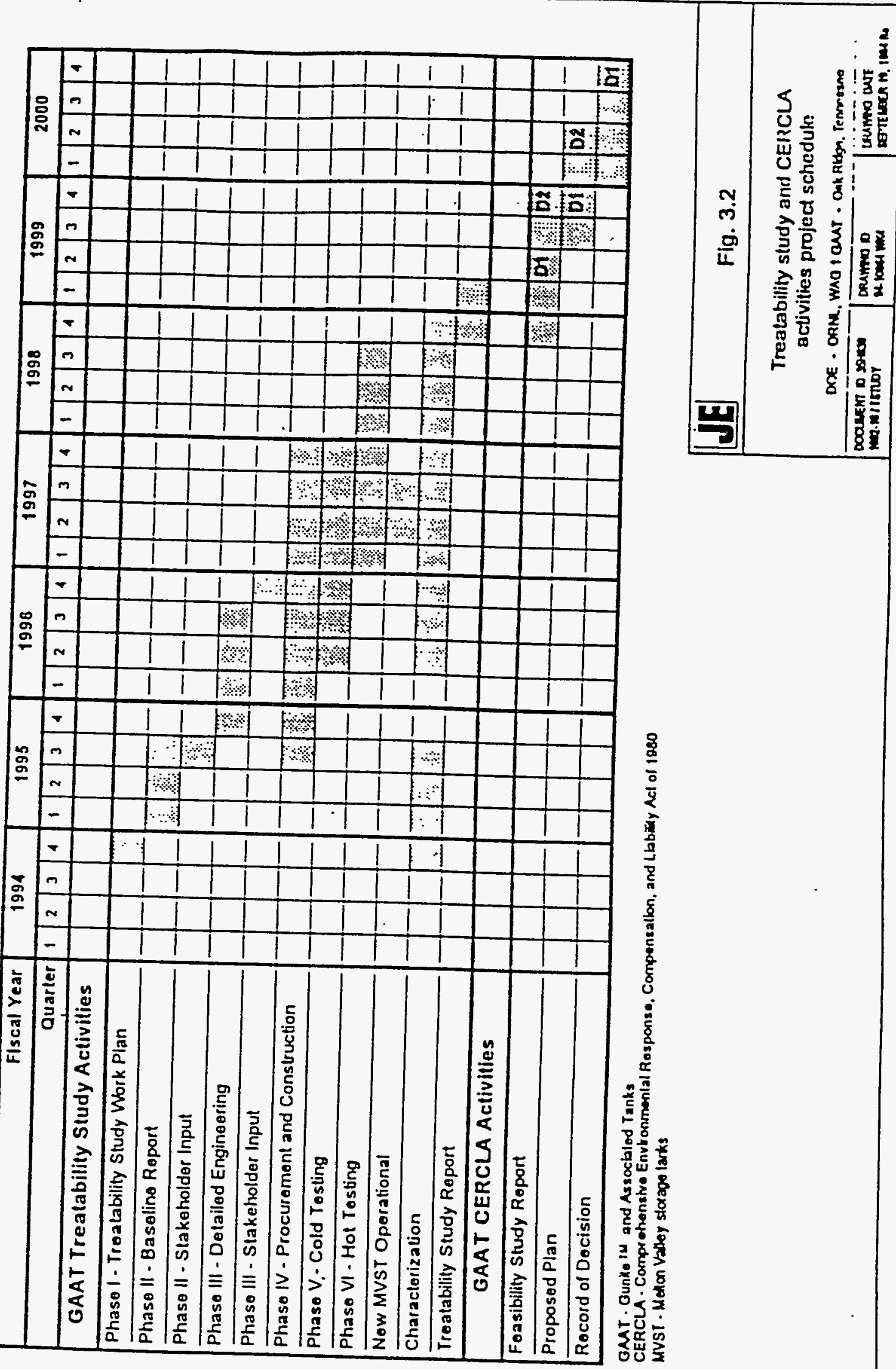

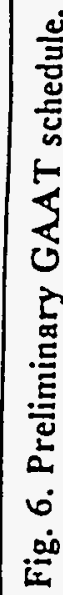




\section{MILESTONES}

Key project milestones are listed here.

Initiate tank sampling 08/15/94

Submit treatability studies work plan Phase I - $\quad 09 / 30 / 94$

D1 to DOE

Submit final project management plan to DOE $\quad 12 / 30 / 94$

Issue draft treatability studies baseline and $\quad 06 / 30 / 95$

work plan Phase II - DI

Initiate support facility construction 08/31/95

Initiate cold tests $\quad 01 / 02 / 96$

Initiate hot tests $\quad 09 / 30 / 96$

Submit draft feasibility study to regulators $\quad 03 / 30 / 99$ 


\section{COST ESTIMATE}

The cost estimate summary for the GAAT Treatability Studies Project is captured in a project life cycle baseline document. The baseline document tracks changes to the cost estimate and is revised annually; therefore, the cost estimate summary will not be included in this project management plan. The baseline document is an internal document and has not been cleared for public release. If information is required on the cost estimate summary, contact the GAAT Treatability Studies Project Manager shown in Fig. 5. 


\section{REFERENCES}

Energy Systems. July 1994. Program Management Plan for the Martin Marietta Energy Systems, Inc. Oak Ridge National Laboratory Site Environmental Restoration Program. ORNL/ER-167. 


\section{DISTRIBUTION}

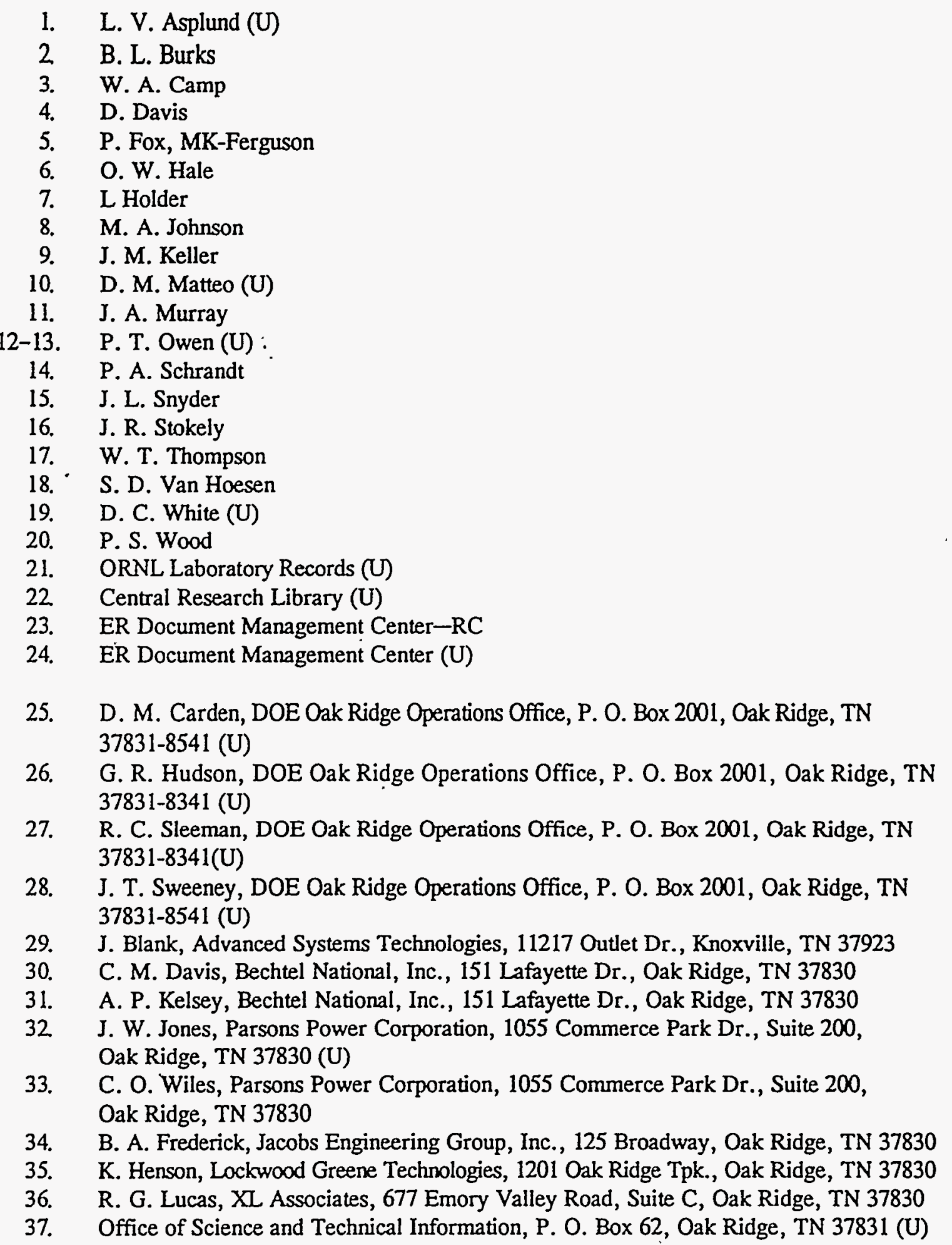

